\title{
ANALISIS EKONOMI DAN PROSPEK USAHA TANAMAN DAN TERNAK SAPI DI LAHAN PERKEBUNAN KELAPA
}

\author{
S. Rusdiana dan Cut R. Adawiyah \\ Pusat Penelitian dan Pengembangan Peternakan \\ Jl. Raya Pajajaran Kav E-59 Bogor 15161 \\ Pusat Analisis Sosial Ekonomi dan Kebijakan Pertanian \\ Jalan Ahmad Yani No.70 Bogor
}

\begin{abstract}
This paper studies the results of the 2012 field survey research area targeted is the location of plantations owned by farmers in the village of Coventry District Leuwi Booths Bogor Regency of West Java, to get a general idea on the land through a pattern of oil palm plantations and the business of cattle through research studies with application of livestock on land that has not produced oil crops (TBM), coconut trees that produce (TM) and coconut trees that do not produce or damaged (TTM / TR) conservation-minded, analissi financial economics. Financial analysis methods is used to determine income from coconut plantations and cattle business. Primary data were obtained directly from the farmers, the secondary data obtained from the relevant authorities and research results. Primary and secondary data collected are tabulated qualitative and quantitative analysis as well as the tables. The results of the financial analysis of the plant economically immature coconut (TBM) gains from the coconut around Rp-3.780.000/tahun/ha because immature coconuts, which means the cost is still in pemeliharana coconut plants, of cattle around Rp5.143.000 / year, whereas immature (TBM) benefits of coconut around Rp6.750.000 / year / ha of cattle around Rp1.972.000/tahun and plants do not produce or damaged plants (TTM / TR) gains from the coconut around Rp1.200.000 of livestock around Rp4.950.000/tahun. It means that utilization of vacant land in coconut plantations damaged by cattle in financial analysis and profitable livestock farmers can maintain the existence of livestock.
\end{abstract}

Keywords : economic analysis, coconut, food crops and livestock

\section{PENDAHULUAN}

Strategi pembangunan daerah perdesaan dilakukan berdasarkan pertumbuhan melalui pemerataan dengan prinsip membangun dari apa yang dimiliki rakyat dan apa yang ada pada rakyat, dengan titik berat pembangunan yang berlandaskan pada pembangunan ekonomi rakyat, pendidikan rakyat, dan kesehatan rakyat, strategi pembangunan yang menjadi pilihan tersebut memerlukan langkah-langkah operasional yang terukur dan disesuaikan dengan paradigma baru pembangunan. Tujuan pembangunan ekonomi daerah di perdesaan adalah meningkatkan standar hidup layak yang diukur dengan indikator pendapatan per kapita riil masyarakat, pendapatan per kapita dan pengeluaran per kapita dapat dijadikan sebagai indikator kemajuan pembangunan ekonomi daerah.

Pemanfaatan lahan kosong perkebunan, baik perkebunan kelapa, kelapa sawit, karet, kakao, lahan kosong pertanian yang belum ditanami dan tanaman tahunan dengan topografi yang bergelombang dapat dimanfaatkan secara maksimal melalui pendekatan ekosistem, baik melalui pola usaha tanaman ternak, rotasi tanaman dalam budidaya lorong ataupun usahatani campuran antara tanaman tahunan, tanaman pangan dan hijauan untuk pakan ternak yang berwawasan konservasi lahan yang tidak merusak lingkungan. Pemanfaatan lahan kosong tersebut dapat dijadikan sumber hijauan pakan ternak sapi potong yang dapat mengurangi pembiyaan usaha pemeliharaan ternak. sehingga akan 


\section{S. Rusdiana, Cut R. Adawiyah : Analisis Ekonomi Dan Prospek Usaha Tanaman ...}

meningkatkan pendapatan petani secara optimal, sehingga akan berpengaruhnyata terhadap kemajuan perekonomian di pedesaan serta mengurangi akan kemiskinan penduduk di pedesaan.

Mencukupi pangan penduduk di Indonesia, tantangan yang dihadapi pada masa yang akan datang tidak hanya terbatas pada upaya peningkatan produksi tetapi juga harus mempertimbangkan keberlanjutan yang berkaitan dengan kelestarian lingkungan. Arsyad (1989). Pemanfaatan lahan kosong dalam rangka pembangunan pertanian khususnya pertanian tanaman pangan dan pemenuhan protein hewani tidak saja menggunakan lahan subur ataupun yang mempunyai irigasi tetapi juga telah diarahkan kepada pemanfaatan lahan marginal Rahmawaty (2002). Kecukupan pakan hijauan dalam arti kuantitas dan kualitas merupakan kebutuhan utama dalam pengembangan biakan ataupun peningkatan populasi sapi potong.

Sumber yang dapat dijadikan sebagai penghasil pakan hijauan ternak dari tahun ketahun semakin berkurang dikarenakan adanya konversi lahan pertanian setiap tahun menjadi pemukiman ataupun non pertanian lainnya BPS (2009), terjadi penyusutan lahan pertanian dengan rata-rata 5\%/tahun, penyebabnya adalah semakin diintensifkannya usaha tanaman pakan serta meningkatnya kebutuhan lahan akibat perkembangan kawasan industri dan perumahan. Sedangkan lahan pertanian merupakan salah satu sumber utama hijauan pakan ternak. Peningkatan populasi ternak sapi potong masih terpaku pada kemampuan suatu wilayah untuk menyediakan hijauan pakan ternak dari limbah tanaman pangan, sementara luas areal sumber pakan ternak baik berupa padang penggembalaan maupun lahan hijauan pakan terus berkurang.

Penyusutan lahan pertanian, musim hujan dan musim kemarau dapat berpengaruh terhadap penyediaan hijauan ternak. Untuk mengimbangi permintaan dan kebutuhan pakan diperlukan delineasi dan pemetaan sumberdaya pakan dan daya dukung lahan yang didasarkan kalkulasi antara sumber pakan dari limbah tanaman pangan dan daya dukung lahan serta penyebaraan ternak sapi potong disetiap komunitas peternak Bamualim (1994). Penanaman leguminose pohon yang bernilai gizi tinggi dan berproduksi selama musim kemarau sebagai salah satu alternatif untuk pemenuhan kebutuhan pakan ternak mutlak dapat diperhitungkan dalam setiap usaha pengembangan ternak sapi potong di daerah semi arid Bamualim (2010).

Kondisi musim kemarau terutama pada bulan Juli-Oktober produksi hijauan pakan ternak mengalami penurunan tajam, yakni sekitar 50\%. Tantangan tersebut diatas harus diubah menjadi suatu peluang untuk terus menumbuh kembangkan usaha ternak sapi potong berbasis sumberdaya domestik yang didukung dengan teknologi inovatif. Keunggulan komparatif yang ada harus dikombinasikan dengan keunggulan kompetitif dalam kegiatan usaha tanman pangan dan ternak sapi potong. Melihat permasalahan di atas maka tujuan dari tulisan ini membahas analisis finansial prospek usaha tanaman dan ternak sapi dilahan perkebunan kelapa yang akan diuraikan secara sederhana, berdasarkan pemanfaatan lahan kosong perkebunan, berdasarkan pendekatan ekosistem dalam analisis ekonomi pendapatan di perdesaan

\section{METODE PENELITIAN}

Kajian tulisan ini hasil penelitian survey lapangan, lokasi yang jadi sasaran adalah lokasi perkebunan kelapa milik petani di Desa Leuwi Bilik, Kecamatan Citeureup Kabupaten Bogor Jawa Barat, pada tahun 2012 dan untuk mendapatkan gambaran umum secara kuantitatif dan kualitatif, lahan kosong perkebunan kelapa dengan ternak sapi potong dengan topografi yang bergelombang dapat dimanfaatkan secara maksimal melalui pendekatan ekosistem, baik melalui pola usaha tanaman pangan dan ternak sapi melalui kajian penelitian dengan penerapan ternak di lahan tanaman kelapa seluas/ha yang belum menghasilkan (TBM), tanaman kelapa yang menghasilkan (TM) dan tanaman kelapa yang tidak menghasilkan atau rusak (TTM/TR) yang berwawasan konservasi, ekonomi dan tanpa merusak lingkungan serta memanfaatkan hijauan pakan ternak yang timbuh disekitar perkebunan kelapa sehingga akan mengurangi biaya usaha pemeliharaan ternak.

Metoda yang digunakan adalah meroda analisis finansial secara ekonomi dari usaha tanaman kelapa dan ternak sapi yang diusahakan oleh petani sehingga terdapat 


\section{S. Rusdiana, Cut R. Adawiyah : Analisis Ekonomi Dan Prospek Usaha Tanaman ...}

perbedaan perbandingan keuntungan antara kelapa dan ternak yang di usahakan oleh petani kelapa dan petani ternak di pedesaaan waktu tertentu/setahun yang didasarkan kepada hasil penelitian Tikupandang et al. (1995). Data primer diperoleh langsung dari petani kepala dan petani ternak sapi, sedangkan data sekunder diperoleh dari Dinas terkait dan hasil penelitian terdahulu yang telah dilaporkan. Data yang dikumpulkan dari hasil penelitian ditabulasi dan diolah secara analisis kualitatif dan kuantitatif dan tabel-tabel ditampilkan

\section{Pemanfaatan Lahan Kosong Perkebunan}

Kelapa Kondisi umum wilayah. Kondisi Geografis dan Administratif, Letak dan Batas Wilayah Kabupaten Bogor merupakan salah satu wilayah di Jawa Barat yang berbatasan langsung dengan DKI Jakarta yang secara geografis terletak antara $6^{\prime} 19^{\circ}-6^{\prime} 47^{\circ}$ lintang selatan dan $106^{\circ} 1^{\prime}-107^{\circ} 103^{\prime}$ bujur timur, dengan luas sekitar 2.301,95 km2, secara administratif batas-batas wilayah Kabupaten Bogor adalah.

- Sebelah utara : Kota Depok

- $\quad$ Sebelah barat : Kabupaten Lebak

- Sebelah barat daya : Kabupaten Tangerang

- Sebelah timur : Kabupaten Purwakarta

- Sebelah timur laut : Kabupaten Bekasi

- Sebelah selatan : Kabupaten Sukabumi

- Sebelah tenggara : Kabupaten Cianjur Kabupaten Bogor memiliki 40 kecamatan dan 428 desa/kelurahan, hampir sebagian besar desa di Kabupaten Bogor sudah terklasifikasi sebagai desa swakarya yakni 237 desa dan 191 desa merupakan desa swasembada, Kabupaten Bogor tidak memiliki desa swadaya dari 40 Kecamatan yang terdapat di Kabupaten Bogor ada dua Kecamatan yang di jadikan sebagai lokasi kajian yaitu Kecamatan Pamijahan dan Kecamatan Leuwiliang. Kedua kecamatan ini merupakan kecamatan yang berbatasan antara keduanya. Adapun secara batas-batas wilayah kedua kecamatan tersebut adalah sebagai berikut :

Batas-batas wilayah Kecamatan Pamijahan :

- Sebelah utara : Kecamatan Leuwiliang dan Cibungbulang

- Sebelah barat : Kecamatan Leuwiliang dan Nanggung

- Sebelah timur : Kecamatan Tenjolaya

- Sebelah selatan : Kabupaten Sukabumi
Batas-batas Kecamatan Leuwiliang :

- Sebelah utara : Kecamatan Cibungbulang

- Sebelah barat : Kecamatan Leuwisadeng dan Nanggung

- Sebelah timur : Kecamatan Ciampea

- Sebelah selatan : Kecamatan Pamijahan

Keadaan alam Kabupaten Bogor. Kabupaten Bogor merupakan daerah yang identik dengan sektor pertanian, topografi wilayah Kabupaten Bogor sangat bervariasi, yaitu berupa daerah pegunungan di bagian selatan hingga daerah dataran rendah di sebelah utara, daerah dataran rendah industri di sebelah timur dan daerah pegunungan, perkebunan dan pertanian di sebelah barat. Fungsi lahan di Kabupaten Bogor tidak hanya di jadikan sebagai pemukiman dan industri, tetapi juga masih banyak potensi lahan yang digunakan untuk pertanian, perkebunan, peternakan, perikanan dan kehutanan. Umumnya struktur tanah di wilayah Kabupaten Bogor terdiri atas tanah regosol dan tanah latosol dengan curah hujan antara 2500 sampai $5000 \mathrm{~mm}$ per tahun. Di Kabupaten Bogor terdapat enam Daerah Aliran Sungai (DAS) besar yang memiliki cabangcabang yang sangat banyak hingga 339 cabang, yaitu meliputi Daerah Aliran Sungai Cisadane, DAS Ciliwung, DAS Cidurian, DAS Cimanceuri, DAS Angke dan DAS Citarum, Disnak Kabupaten Bogor (2012)

Pemanfaatan lahan kosong perkebunan. Pemanfaatan yang dimaksudkan dalam hal ini adalah beberapa alternatif pola pemanfaatan yang menurut beberapa ahli dapat diterapkan berdasarkan pendekatan ekosistem pada lahan kosong perkebunan, baik perkebunan kelapa, kelapa sawit, kakao, karet dan hutan atau kering PMK yang beriklim basah dengan topografi bergelombang yang dapat di tumapangsarikan dengan tanaman jagungm, seperti : ubi kayu, kacang tanah, ubi jalar, padi huma dan ubi jalar, tetapi tidak mengurangi akan cahaya matahari yang dipantulkan lewat tanaman tersebut, beberapa alternatif tersebut dapat dikemukakan sebagai berikut:

Penerapan usaha tani ternak. Usaha tani tanaman-ternak yang dapat diusahakan menanam tanaman pangan, antara tanaman di lahan kosong perkebunan kelapa, kelapa sawit, karet, kakao dan lahan kosong yang belum ditanami. Tanaman pangan yang diusahakan adalah jagung varietas unggul (Arjuna), kedelei (Wilis) dan ubi kayu (Adira), sedangkan padi 


\section{S. Rusdiana, Cut R. Adawiyah : Analisis Ekonomi Dan Prospek Usaha Tanaman ...}

gogo yang diusahakan adalah varietas lokal (Sirendah Bulat) karena varietas ini toleran terhadap penyakit. Teknologi yang menyangkut keberhasilan pangan seperti prinsip Pengendalian Hama Terpadu (Integrated Pest Management) dan Pengendalian Gulma Terpadu (Integrated Weed Management), penggunaan sabir bergerigi, pemakaian tresher dan lain-lain tetap diupayakan Anwarham dan Supriadi (1997).

Usahatani campuran adalah sistem pertanaman yang mencakup tanaman pangan, tanaman tahunan, tanaman penahan erosi, dan tanaman pakan ternak, sedangkan serasering dibuat untuk membantu mengurangi bahaya erosi dan memperbaiki tata air Samingan (1998), dibawah tanaman tahunan, seperti tanaman kelapa, karet, sawit dan lainnya yang dapat ditanam kacang panjang, jagung, huma padi atau tanaman kacang-kacangan lainnya yang dari limbah tanaman pangan dapat dimanfaatkan untuk pakan ternak ruminansia khusunya sapi potong. Penyediaan pakan untuk burung, pada bagian pinggir dapat ditanam pohon tahunan, sedangkan pada pinggir teras dapat ditanam tanaman kelapa dan pakan hijuan yang dapat menghasilkan secara ekonomi. Pada pinggiran teras dapat juga ditanam tanaman penutup tanah untuk mengurangi laju erosi atau dapat juga ditanam talas.

Tanaman pakan ternak yang dapat ditanam adalah rumput gajah, lamtoro, setaria, Flemingia dan Glyricidia yang dapat difungsikan sebagai tanaman lorong di terasteras untuk mengurangi erosi dan menambah bahan organik dan mineral tanah. Usahatani tanaman ternak telah diterapkan dan dikembangkan di beberapa daerah di Indoensia salahsatu anya dadalah daerah di Batumarta (Sumatera Selatan), Tulang Bawang Tengah (Lampung) dan Air Manganyau (Bengkulu). Analisis usaha dalam pemenuhan kebutuhan pakan ternak ruminansia dengan penanaman hijauan pakan ternak dengan penanaman rumput gajah yang dilakukan dengan metoda perbanyakan vegetatif yang umum diterapkan oleh petani ternak di Indonesia adalah dengan stek batang dan memecah anakan, sehingga dapat memenuhi kebutuhan ternak sapi potong di petani.

Penentuan kelas kesesuaian lahan. Pemilihan komoditas dan teknologi usahatani ternak pada lahan kosong perkebunan kelapa tertentu, kelas kesesuaian lahan harus dipertimbangkan, penentuan kelas kesesuaian lahan harus sudah didukung oleh data iklim, terutama untuk keperluan perencanaan yang bersifat mikro. Curah hujan misalnya perlu diketahui untuk merencanakan waktu dan pola tanam; data jumlah dan intensitas hujan diperlukan untuk memilih teknologi konservasi. Disamping itu, secara lebih jelas dinyatakan bahwa pendekatan sistem ekologis minimal mengandung empat point penting, yaitu: air tidak terganggu, tanaman kelapa tumbuh dengan baik, hijauan yang tumbuha di bawah naungan pohon kelapa tumbuh dengan baik, lingkungan lestari, dan berguna bagi masyarakat khusunya petani ternak sapi potong. Sedangkan dalam menentukan jenis tanaman dan tata tanam perlu dipertimbangkan, diantaranya : hal-hal seperti: Besarnya nilai evapotranspirasi jika dibandingkan dengan curah hujan, stem flow, yaitu memperhatikan aliran air dari daun ke batang lalu ke tanah yang nantinya berhubungan dengan bahaya erosi, allelopati dan allelokimia diperhatikan dalam hubungannya dengan jarak tanam, mempertimbangkan tanaman penyelenggara ecologycal niche, mendukung keadaan sosial dan budaya masyarakat setempat, tata tanam campuran yang dapat menghindarkan hama dan penyakit dan tanaman yang bernilai ekonomi. Terdapat sumberdaya manusia yang merupakan faktor dominan dalam untuk pembangunan menggunakan pendekatan ekosistem, dalam penggunaan dan pengelolaan sumberdaya secara bijaksana dalam rangka mengupayakan pembangunan yang berkesinambungan, tingkat pengetahuan dan kesadaran mengenai pentingnya kualitas lingkungan hidup merupakan hal penting disamping kepadatan penduduk dan kebudayaan masyarakat.

Pemanfaatan lahan kosong perkebunan kelapa yang mempunyai sipat tanah atau lahan kering Podsolik merah kuning beriklim basah dengan topografi bergelombang memerlukan pendekatan ekosistem yaitu adanya interaksi antara beberapa komoditas sehingga keadaan lingkungan tetap baik. Sebagai contoh, laju erosi dapat dikendalikan, penerapan ternak sapi potong di lahan kosong perkebunan kelapa dapat mempertahankan kesuburan lahan dan optimasi pemanfaatan tanaman kembali 


\section{S. Rusdiana, Cut R. Adawiyah : Analisis Ekonomi Dan Prospek Usaha Tanaman ...}

\section{Prospek Pengembangan Usaha Tanaman dan Ternak}

Kontribusi usaha tanaman ternak. Dari segi luas, lahan kering PMK di Indonesia mencapai 47.6 juta ha, namun demikian berdasarkan kemiringan lerengnya lahan yang potensial untuk produksi pertanian adalah kurang dari $15 \%$ atau bergelombang, berbagai untuk menangani lahan kritis seperti lahan kering PMK adalah melalui program reboisasi dan penghijauan, Tanaman pagar berfungsi sebagai penahan erosi dan penghasil bahan organik yang dapat meningkatkan produktivitas lahan IPB (1987) dalam Hakim et al, (1997). Usaha tanaman terpadu tanaman-ternak yang tersiri dari tanaman pangan, ternak dan karet dapat meningkatkan pendapatan petani Anwarhan dan Supriadi (1997), masalah kemasaman tanah dapat diperbaiki terlebih dahulu misalnya menggunakan kapur atau bahan organik sebelum dilakukan pemupukan Arief dan Irman (1997). Untuk mengurangi erosi, menyuburkan tanah, sumber pakan ternak diperlukan penerapan sistem usaha tani konservasi seperti pertanaman lorong dengan menggunakan tanaman pepohonan sebagai tanaman pagar hidup Basri, (1997) dan pengurangan masukan sarana produksi dan tata tanam yang tepat Noorginawati et al, (1997), tanaman penutup tanah dapat pula ditanam khusus untuk melindungi tanah dari ancaman kerusakan oleh erosi dan atau untuk memperbaiki sifat kimia dan fisik tanah Arsyad (1989). Disamping itu, pergiliran tanaman dapat dilakukan dengan cara penanaman berbagai tanaman secara bergilir dalam urutan waktu tertentu pada sebidang tanah. Akhirnya pertanian-hutan (agroforestry dapat pula dijadikan alternatif pemanfaatan lahan kering PMK beriklim basah dengan topografi bergelombang.

\section{Kondisi Perkebunan Kelapa dan Penyebarannya}

Kondisi Perkebunan Kelapa di Indonesia. Tanaman kelapa merupakan komoditas yang paling luas penyebarannya di wilayah Nusantara. Tanamana ini mulai berbuah antara 5-6 tahun dan mampu hidup lebih dari 50 tahun Anikumar dan Wahid (1998). Oleh karenanya luas areal TTM dan TR cenderung terus meningkat, dan secara nasional sudah mencapai 9,97\%. Komoditas ini merupakan bagian yang tidak terpisahkan dari kehidupan masyarakat, dengan peran yang berbeda-beda. Peran komoditas kelapa dalam kehidupan masyarakat mulai dari pemenuhan untuk kebutuhan sosial dan budaya sampai untuk kepentingan ekonomi yang secara langsung menjadi tumpuhan kehidupan petani. Oleh karenanya kelapa juga dijuluki sebagai 'Tree of life', atau pohon kehidupan.

Prospek SUKT Sapi-kelapa Secara In-situ. Negara-negara Asia Tenggara, konsep pertanian terpadu yang melibatkan pola sistem integrasi tanaman-ternak, sebenarnya sudah diterapkan oleh petani di Indonesia sejak jaman dahulu. Berbagai varian dari penerapan pola ini cukup beragam berdasarkan tingkat pemilikan petani, Devendra (1993). Pada awal revolusi hijau, sistem usahatani terpadu mulai diperkenalkan pada tahun 1970-an berdasarkan hasil-hasil pengkajian dan penelitian yang dimulai oleh Lembaga Pusat Penelitian Pertanian (LP3) di Bogor dengan mengacu pada pola di IRRI. Sejak saat itu secara bertahap muncul istilah-istilah pola tanam(cropping pattern), pola usahatani (cropping systems), sampai akhirnya muncul istilah "sistem usahatani (farming systems), serta sistem integrasi tanaman-ternak yang merupakan terjemahan dari crop livestock systems atau CLS Diwyanto, (2008); Kusnadi, (2008). Terlihat pada Tabel.1.

Devendra, (1993) menyatakan bahwa terdapat delapan keuntungan dari penerapan pola sistem integrasi tanaman-ternak, yaitu: (1) diversifikasi penggunaan sumberdaya produksi, (2) mengurangi terjadinya resiko usaha, (3) efisiensi penggunaan tenaga kerja, (4) efisiensi penggunaan input produksi, (5) mengurangi ketergantungan energi kimia dan biologi serta masukan sumberdaya lainnya, (6) sistem ekologi lebih lestari serta tidak menimbulkan polusi sehingga ramah lingkungan, (7) meningkatkan output, dan (8) mampu mengembangkan rumahtangga petani yang berkelanjutan. Ke delapan keuntungan ini diperoleh karena adanya sinergi antar kegiatan, yang pada gilirannya hampir tidak ada sumberdaya yang terbuang (zero waste). 
S. Rusdiana, Cut R. Adawiyah : Analisis Ekonomi Dan Prospek Usaha Tanaman ...

Tabel 1. Sistem Integrasi Tanaman-Ternak di Asia Tenggara

\begin{tabular}{llll}
\hline \multicolumn{1}{c}{ Komoditas/Ternak } & Tujuan Produksi & Tipe Tumpang Sari & Tingkat Kepemilikan \\
\hline Kerbau & Tenaga Kerja & Padi, Palawija & Tinggi \\
& Daging & Padi & Tinggi \\
Sapi & Daging & Horti, Padi, Kebun & Tinggi \\
& Susu & Horti, Kebun & Tinggi \\
& Tenaga Kerja & Padi, Palawija & Tinggi \\
Kambing & Daging & Horti, Kebun & Sedang/Tinggi \\
& Susu & Horti, Kebun & Rendah \\
Domba & Daging & Horti. Kebun & Sedang/Tinggi \\
\hline
\end{tabular}

Sumber: DEVENDR., (1993) (dimodifikasi) dalam Diwyanto et al., (2010)

Implikasinya adalah beberapa produk yang dihasilkan dapat diperoleh tanpa biaya yang secara riil harus dikeluarkan petani/peternak (zero cost). Hasil penelitian dan pengkajian pola integrasi sapi di bawah pohon kelapa (Sulawesi Utara), sapi di kawasan persawahan (Jawa, Bali, Sulawesi Selatan, NTB), mina-padi di Jawa Barat, integrasi ternak di lahan tadah hujan di Bali, Lampung dan Jawa Barat menunjukkan bahwa penerapan model integrasi tanaman-ternak sudah dapat diterima oleh masayarakat. Integrasi sapi dengan padi pada pola tanam IP-300 di beberapa wilayah menunjukkan hasil dan keuntungan ekonomi yang relatif lebih tinggi, dibandingkan jika usaha tersebut dilaksanakan secara monokultur.

Diwyanto et al., (2002) menyatakan bahwa penerapan sistem ini meningkatkan penghasilan petani hampir dua kali lipat lebih tinggi apabila dibandingkan dengan pola tanam padi tanpa ternak.Sekitar 40 persen dari hasil tersebut berasal dari pupuk organik yang diperoleh dari ternak sapi. Hasil-hasil penelitian dan pengkajian di berbagai tempat dan agroekologi juga menunjukkan bahwa pada umumnya integrasi ternak dengan tanaman, baik itu tanaman pangan, tanaman perkebunan maupun tanaman industri memberikan nilai tambah yang cukup signifikan Diwyanto et al. (2004); Mhatius. (2008); Kusnadi (2008), Haryanto.(2009).

Perkebunan kelapa mempunyai peluang untuk dikembangkan menjadi kawasan usaha ternak sapi potong khususnya usaha cow calf operation (CCO) pola integrasi CLS secara insitu. Dalam hal ini ternak dapat dipelihara atau digembalakan dibawah naungan pohon kelapa yang sudah cukup besar, sehingga tidak dapat dirusak oleh sapi. Subagyono (2004), menyatakan bahwa di perkebunan terdapat kelimpahan biomasa yang dapat dimanfaatkan untuk pakan ternak yang berupa: (i) rerumputan yang tumbuh dibawah naungan pohon kelapa, (ii) limbah dari hasil tanaman sela yang dibudidayakan secara tumpang sari, atau (iii) limbah yang berasal dari pengolahan produk kelapa terutama bungkil kelapa yang berkualitas sangat tinggi. Diperkirakan sedikitnya $10-30 \%$ perkebunan kelapa dapat dimanfaatkan untuk pengembangan usaha $\mathrm{CCO}$ dalam suatu SUKT pola integrasi in-situ. Terlihat pada Tabel.2.

Pada umumnya tanaman kelapa yang masih muda mempunyai kanopi daun yang menahan sinar matahari mencapai permukaan tanah, sehingga membatasi perkembangan

Tabel. 2. TPT yang Cocok untuk Sistem Penggembalaan Ringan

\begin{tabular}{lll}
\hline & No & \multicolumn{1}{c}{ Nama botani } \\
\hline 1. & B. humidicola & Rumput beha \\
2. & Andropogon gayanus & Rumput gamba \\
3. & Digitaria decumbens & Rumput pangola \\
4. & Centhrus ciliaris & Rumput baffel \\
5. & Stylosanthes spp. & Stilo \\
6. & Macroptilium antropurpureum & Siratro \\
\hline
\end{tabular}

Sumber: Prawiradiputra, et al.,, (2006) dalam Diwyanto et al., (2010) 


\section{S. Rusdiana, Cut R. Adawiyah : Analisis Ekonomi Dan Prospek Usaha Tanaman ...}

pertumbuhan tanaman di bawahnya. Namun demikian terdapat beberapa jenis tanaman yang mampu tumbuh dibawah naungan dan dapat digunakan sebagai pakan ternak antara lain Calopogonium, Centrocema dan Arachis Prawiradiputra et al. (2006). Potensi pengembangan TPT pada lahan perkebunan dapat ditingkatkan melalui modivikasi penggunaan lahan pada lajur diantara dua tanaman utama, atau yang dikenal dengan istilah tanaman sela. Jenis tanaman sela yang akan diusahakan sangat tergantung dari sifat karakteristik lahan pada areal perkebunan kelapa.

Beberapa TPT yang mungkin dapat dikembangkan di perkebunan kelapa meliputi rerumputan atau tanaman leguminosa dengan daya tahan penggembalaan ringan, Sapi yang dipelihara dalam kawasan ini sangat ideal bila dikandangkan secara terus menerus agar tidak merusak tanaman pokok yang masih muda. Keuntungan dari sistem pemeliharaan seperti ini adalah, kotoran dapat dikumpulkan dengan mudah, yang selanjutnya dapat dimanfaatkan untuk dijadikan kompos atau biogas. Inovasi seperti yang dikembangkan Loka Penelitian Sapi, Grati, dengan pendekatan LEISA (low external input sustainable agriculture) dapat diaplikasikan secara mudah dan murah. Terlihat pada Tabel.3

Perkebunan yang dalam katagori TM, terutama yang relatif sudah cukup besar, maka pemeliharaan ternak dapat dilakukan dengan cara digembalakan atau grazing. Semakin tinggi pohon kelapa maka intensitas cahaya yang dapat mencapai permukaan tanah juga semakin banyak Mahmud, (2008). Sementara itu kerapatan perakaran kelapa juga relatif sangat longgar hanya sekitar 2 meter, padahal jarak tanamnya sekitar 10x10 meter. Oleh karena itu bila ditinjau dari radiasi matahari maupun sistem perakaran pohon kelapa, pola tumpangsari dengan TPT sangat prospektif. Jenis TPT yang tahan injakan atau senggutan yang mungkin dapat dikembangkan disini tercantum dalam Tabel 4 dan 5. Bila saat ini luas areal perkebunan kelapa dalam katagori TM secara nasional lebih dari 3 juta ha, dan 10 persen diataranya dapat dilakukan SUKT dengan sapi, maka berpotensi untuk mengembangkan usaha CCO sekitar 500-700 ribu ekor sapi, hal ini berarti berpotensi memberi tambahan pasokan feeder cattle sebanyak 50 persen dari yang diperlukan untuk mewujudkan PSDS 2014.

Tabel 3 Beberapa Contoh TPT yang Cocok untuk Potongan

\begin{tabular}{lll}
\hline No & \multicolumn{1}{c}{ Nama botani } & \multicolumn{1}{c}{ Nama umum } \\
\hline 1. & Pennisetum purpureum & Rumput gajah \\
2. & Pennisetum purpuroides & Rumput raja \\
3. & Panicum maximum & Rumput benggala \\
4. & Euchlaena mexicana & Rumput mexico \\
5. & Calliandra calothyrsus & Kaliandra \\
6. & Gliricidia sepium & Gamal \\
7. & Leucaena leucocephala & Lamtoro \\
\hline
\end{tabular}

Sumber: Prawiradiputra, et al.,(2006) dalam Diwyanto et al., (2010)

Tabel 4. TPT yang Cocok untuk Sistem Penggembalaan Berat

\begin{tabular}{lll}
\hline No & \multicolumn{1}{c}{ Nama botani } & \multicolumn{1}{c}{ Nama umum } \\
\hline 1. & Brachiaria decumbens & Rumput signal \\
2. & Paspalum dilatatum & Rumput australi \\
3. & Paspalum notatum & Rumput bahia \\
4. & Cynodon dactylon & Rumput kawat \\
5. & Calopogonium muconoides & Kalopo \\
6. & Pueraria phaseloides & Puero \\
\hline
\end{tabular}

Sumber: Prawiradiputra rt al., (2006) dalam Dwiyanto et al., (2010) 


\section{S. Rusdiana, Cut R. Adawiyah : Analisis Ekonomi Dan Prospek Usaha Tanaman ...}

Tabel 5 Teknologi Inovatif untuk Mendukung SUKT dengan Sapi Potong

\begin{tabular}{|c|c|c|}
\hline No & Jenis kegiatan & Aktivitas \\
\hline 1. & Pengolahan Lahan & $\begin{array}{l}\text { Pembajakan, penggaruan dan pengapuran bila diperlukan, } \\
\text { pembuatan drainase, serta penghalusan tanah bila yang ditanam } \\
\text { biji. }\end{array}$ \\
\hline 2. & Pemilihan benih/bibit & $\begin{array}{l}\text { Penetapan jenis atau spesies, seleksi benih, pengujian daya } \\
\text { kecambah, perendaman dengan pestisida, serta inokulasi } \\
\text { dengan rhizobium yang cocok untuk legume. }\end{array}$ \\
\hline 3. & Penanaman & $\begin{array}{l}\text { Penebaran biji secara tepat, penyiraman benih bila } \\
\text { kemarau/kering,dan penggunaan sistem galur. }\end{array}$ \\
\hline 4. & Pemupukan & $\begin{array}{l}\text { Pengomposan atau pemberian bahan organik dan pemberian } \\
\text { pupuk kimia sesuai kondisi lahan. }\end{array}$ \\
\hline 5. & Penyiangan & $\begin{array}{l}\text { Untuk tanaman kombinasi rumput \& legume tidak memerlukan } \\
\text { penyiangan, tetapi bila ada gulma perlu dihilangkan. }\end{array}$ \\
\hline 6. & Pengaturan penggembalaan & $\begin{array}{l}\text { Menentukan stocking rate agar tidak terjadi over grazing } \\
\text { maupun } \text { under grazing, serta pemagaran dan perotasian ternak. }\end{array}$ \\
\hline 7. & Pengawetan pakan & Pembuatan hay, silage, serta pembangunan feed bank. \\
\hline
\end{tabular}

Sumber: Prawiradiputra, et al.,. (2006); dalam Diwyanto et al., (2010)

Tabel.6. Potensi Daya Tampung Ternak Sapi Potong di Lahan Perkebunan Kelapa di Indnesia

\begin{tabular}{lllll}
\hline \multicolumn{1}{c}{ Uraian } & & \multicolumn{3}{c}{ Status Tanaman Kelapa } \\
\hline & Lahan Kosong & TBM & \multicolumn{1}{c}{ TM } & TTM/TR \\
Luas lahan kelapa ( ha) & & 620.000 & 2.790 .000 & 369.919 \\
Hijauan alami ( ST/ha) & 0.5 & 0.5 & 0.09 & 0.4 \\
Daya tampung ( ST) & & 310.000 & 251.100 & 147.967 \\
\hline
\end{tabular}

Keterangan; TBM ( Tanaman Belum Menghasilkan), TM (Tanaman Menghasilkan), TTM /TR (Tanaman Tidak Menghasilkan/ Tanaman Rusak).

Inovasi yang diperlukan disini adalah dalam hal penetapan jenis atau spesies TPT yang layak dikembangkan sesuai agroekologinya. Disamping itu juga diperlukan suatu inovasi terkait dengan penyediaan benih, penanaman serta pengelolaan TPT, agar pengembangan TPT secara teknis mudah dan layak ekonomis. Penanaman kelapa secara monokultur ternyata dapat menyediakan lahan dan ruang yang luas di atas tanah. Lahan yang tersisa tersebut dapat dimanfaatkan untuk tanaman sela untuk pangan maupun pakan Mahmud (2008).

Areal lahan diantara baris tanaman kelapa pada Status TBM dan TM yang secara nasional berjumlah 3,4 juta ha, dan areal lahan perkebunan yang perlu segera diremajakan sebanyak 0,37 juta ha merupakan kawasan yang berpotensi untuk dikembangkan tanaman sela. Pola tumpang sari seperti ini sudah banyak dilakukan di Bali atau Jawa, seperti yang dianjurkan Nitis et al. (2004) dalam pola tiga strata. Pemilihan jenis komoditas yang dikembangkan secara tumpang sari seperti ini harus diasarkan pada nilai manfaat secara teknis, ekonomis, sosial, budaya serta dengan tetap menjaga kelestarian lingkungan. Terlihat pada Tabel. 6

Setiap pohon kelapa menggunakan luas effektif $(2 \times 2) \times 3,14=12,56 \mathrm{~m}^{2} \quad\left(13 \mathrm{~m}^{2}\right.$, setiap ha lahan kelapa sekitar 130 pohon, jadi luas effektinya adalah $13 \mathrm{~m}^{2} \times 130$ pohon sekitar $1.690 \mathrm{~m}^{2}$. Sehingga dalam 1 ha $\left(10.000 \mathrm{~m}^{2}\right)$ masih ada lahan sebanyak 10.000 $1.690 \mathrm{~m}^{2}$ jadi sekitar $8.310 \mathrm{~m}^{2}$. Luas ini dapat digunakan untuk penanaman tanaman sela. Kapasitas produksi hijauan/ha dalam penggembalaan ringan sekitar 55ton hijauan segar, dengan daya dukung 5 ekor ternak sapi potong, seangkan dalam penggembalaan sedang sekitar 100 ton segar, daya dukung 9 ekor sapi. Jika tanaman rumput pangonan penggembaalan ringan sekitar 0.831 x 55 ton hijauan segar sekitar 45.7 ton hijauan segar, pada setiap 55 ton hijauan segar dengan daya tampung 5 ekor ternak sapi potong pada lahan 1 ha pohon kelapa mempunyai daya tampung sekitar 45,7/55 x 5 sekitar 4,1 ekor ternak sapi potong. Jika tanaman rumput pangonan penggembalaan sedang sekitar 0.8310 x 100 


\section{S. Rusdiana, Cut R. Adawiyah : Analisis Ekonomi Dan Prospek Usaha Tanaman ...}

Tabel .7. Potensi Produksi Hijuan Segar (000 ton) dan Daya Tampung Ternak ( ST) pada Lahan Kebun Kelapa

\begin{tabular}{llll}
\hline \multicolumn{1}{c}{ Uraian } & & \multicolumn{2}{l}{ Status Tanaman Kelapa } \\
\hline & TBM & TM & TTM/TR \\
Luas lahan kelapa ( ha) & 620.000 & 2.790 .000 & 369.919 \\
Hijauan alami ( ST/ha) & 0.5 & 0.09 & 0.4 \\
Daya tampung ( ST) & 310.000 & 251.100 & 147.967 \\
Penggembalaan ringan & & & \\
Digitaria decumbens (ton) & 28.334 .000 & 127.503 .000 & 16.905 .298 \\
Daya tampung ( ek) & 2.542 .000 & 11.439 .000 & 1.516 .668 \\
Daya tampung ( ST) & 1.779 .400 & 16.341 .428 & 1.061 .667 \\
Penggembalaan sedang & & & \\
Setaria spp (ton) & 51.522 .000 & 231.849 .000 & 30.740 .268 \\
Daya tampung ( ek) & 4.588 .000 & 20.646 .000 & 2.737 .740 \\
Daya tampung ( ST) & 3.211 .600 & 14.452 .200 & 1.916 .418 \\
Penggembalaan berat & & & \\
Brachiaria humidicola (ton) & 64.356 .000 & 287.649 .000 & 38.138 .648 \\
Daya tampung ( ek) & 5.146 .000 & 23.157 .000 & 3.070 .328 \\
Daya tampung ( ST) & 3.602 .200 & 16.209 .900 & 2.149 .229 \\
Rumput potong & & & \\
Pennisetum purpurium(ton) & 180.296 .000 & 811.332 .000 & 107.572 .445 \\
Daya tampung (ekor) & 15.810 .000 & 73.935 .000 & 9.432 .934 \\
Daya tampung ( ST) & 11.067 .000 & 51.754 .500 & 6.603053 \\
\hline
\end{tabular}

Keterangan: TBM ( Tanaman Belum Menghasilkan), TM (Tanaman Menghasilkan), TTM /TR ( Tanaman Tidak Menghasilkan/ Tanaman Rusak).

ton hijauan segar sekitar 83,1 ton hijauan segar setiap 100 ton daya tampung untuk 9 ekor ternak sapi potong, jadi pada luas 1 ha kebun kelapa sekitar 83,1/100 × 9 dapat menampung sekitar 7,4 ekor/th. Jika tanaman rumput pangonan penggembalaan berat sekitar $0.831 \mathrm{x}$ 125 ton hijauan segar sekitar 103.8 ton hijauan segar, setiap 125 ton menampung 10 ekor ternak spai potong, jadi dalam 1 ha lahan kelapa mampu menampung 103.3/125 x 10 sekitar 8,3 ekor ternak spai potong. Jika tanaman yang digunakan adalah rumput potong maka produksi hijauannya sekita 0.831 x 350 sekitar 290.8 ton hijauan segar. Dengan kemampuan daya tampung sebanyak 290.8/350 x 32 sekitar 26,5 ekor/th. Jadi dalam 1 ha lahan kelapa mempunyai daya tampung sebanyak 26.5 ekor/th. Tabel. 7.

\section{Analisis Finansial Usaha Ternak Sapi di Lahan Perkebunan Kelapa}

Analisis finansial dan kelayakan usaha tanaman kelapa dan ternak sapi. Petani memiliki peran yang sangat penting dalam mengelola lahan pertanian khususnya usahatani ternak dan dapat disimpulkan bahwa ternak sapi mempunyai peranan sangat penting dalam sistem usahatani dan secara finansial, pemilikan ternak dapat memberikan arti tersendiri bagi petani, sebagai salah satu kekayaan yang dimiliki. dan penyangga kebutuhan serta dapat menyediakan biaya untuk kelancaran usahatani, karena sewaktuwaktu dapat dijual dengan mudah, sehingga dapat menekan biaya produksi usaha beternak sapi di samping sumber pupuk organik yang dapat dikembalikan ke lahan pertanian sendiri.

Pendapatan merupakan selisih antara total penerimaan dengan biaya-biaya selama pemeliharaan ternak sapi Menurut Mubyarto (1980), perkiraan pendapatan merupakan hasil usaha pemeliharaan ternak selama periode tertentu. Sedangkan Gittinger (1986), menyatakan bahwa analisis perkiraan ekonomi adalah hasil usaha pemeliharaan ternak yang digunakan untuk mengevaluasi kegiatan usaha dalam satu tahun atau dalam periode tertentu. Hasil penelitian dari usaha pemeliharaan ternak sapi nilai jual ternak di lokasi penelitian cukup tinggi sehingga secara tidak langsung sangat menguntungkan peternak dan sekaligus sebagai pemacu untuk mempertahankan keberadaan ternak sapinya. Pendapatan usaha ternak sapi dan kelapa cukup baik dalam mendukung ekonomi finansial peternak. 


\section{S. Rusdiana, Cut R. Adawiyah : Analisis Ekonomi Dan Prospek Usaha Tanaman ...}

Analisis finansial secara ekonomi untuk mengetahui tingkat keuntungan yang diperoleh petani dalam penggunaan tenaga kerja dan biaya yang dikeluarkan di samping bibit, sedangkan untuk mengetahui pendapatan selama satu tahun yang diterima oleh petani pada saat petani panen atau menjual hasil usahanya Amik et al. (2006). Hasil survey di lapangan menunjukkan, bahwa petani ternak sapi dan hasil kelapa dalam pemeliharaan selama satu tahun pendapatan kotor dan bersih dan pengaruh biaya, tenaga kerja serta jumlah pemilikan ternak di pedesaan nilai sosial ekonomi rumah tangga dan budayanya sangat baik. Metode analisis ini merupakan angka banding antara penerimaan dan biaya yang dikeluarkan pada suatu usaha.

Pengembangan usaha kelapa dan ternak. Areal tanaman kelapa di Indonesia diperkirakan sekitar 3,90 juta ha Ditjenbun (2010), dimana $98 \%$ nya merupakan perkebunan rakyat yang melibatkan juta-an rumah tangga petani. Namun saat ini pengembangan usaha kelapa menghadapi banyak masalah seperti yang telah di review oleh Luntungan (2008) : (i) lahan sempit, kurang dari 0,5 ha; (ii) produktivitas kelapa rendah, rata-rata 1 ton kopra/ha dan diusahakan secara monokultur; (iii) sebagian besar bukan varietas unggul; (iv) belum tersentuh teknologi inovatif; (v) sebagian besar tanaman berumur tua lebih dari 50 tahun.

Komposisi areal perkebunan kelapa rakyat yang sangat luas tersebut terdiri atas: (i) tanaman belum menghasilkan (TBM) sekitar $16,47 \%$; (ii) tanaman menghasilkan (TM) sekitar 73,75\%; dan (iii) tanaman tidak menghasilkan atau tanaman rusak (TTM/TR) sekitar 9,77\%. Perkembangan luas areal TTM/TR selama 5 tahun terakhir di beberapa wilayah cenderung terus meningkat Ditjenbun, (2007) yang secara total diperkirakan telah mencapai 370 ribu ha. Kondisi ini akan berakibat pada rendahnya pendapatan petani, sehingga perlu ada upaya agar pendapatan petani dapat meningkat. Contoh perhitungan produksi hijauan dalam pemanfaatan lahan kosong perkebunan kelapa dan daya tampung ternak terlihat pada Tabel.8-9

Tabel 8. Potensi Produksi Hijauan ( ton/ha/th) dan Daya Tampung Ternak

\begin{tabular}{|c|c|c|}
\hline Jenis Rumput & Produksi ( ton/ha) & Daya tampung ternak \\
\hline \multicolumn{3}{|l|}{ Hijauan alami } \\
\hline \multicolumn{3}{|l|}{ Paspalum } \\
\hline Axonopus compresus & $1-3$ ton bk & $0,8 \mathrm{ST}$ \\
\hline \multicolumn{3}{|l|}{ Penggembalaan ringan } \\
\hline Brachiaria humidicola & $100-150$ ton segar & 9 - 13 ekor sapi (300kg) \\
\hline Digitaria decumbens & $53-55$ ton segar & 5 ekor sapi ( $300 \mathrm{~kg}$ ) \\
\hline Cenchrus ciliaris & $30-40$ ton segar & 2-3 ekor sapi (300 kg) \\
\hline \multicolumn{3}{|l|}{ Penggembalaan Sedang } \\
\hline \multicolumn{3}{|l|}{ Chloris gayana } \\
\hline \multicolumn{3}{|l|}{ Brachiaria mutica } \\
\hline \multicolumn{3}{|l|}{ Cynodon plectostachyus } \\
\hline Setaria spp & $100-110$ ton segar & $9-11$ ekor sapi ( $300 \mathrm{~kg})$ \\
\hline \multicolumn{3}{|l|}{ Penggembalan berat } \\
\hline \multicolumn{3}{|l|}{ Brachiaria decumbens } \\
\hline Paspalum dilatatum & $1-3$ ton bahan kering & $0,8 S T$ \\
\hline \multicolumn{3}{|l|}{ Paspaulum notatum } \\
\hline Cynodon dactylon & 7 ton bahan kering & $2-3 S T$ \\
\hline \multicolumn{3}{|l|}{ Rumput potong } \\
\hline Pennisetum purpurium & $350-525$ ton segar. & $32-46$ ek sapi (300kg) \\
\hline \multicolumn{3}{|l|}{ Pennisetum purpoides } \\
\hline Panicum maximum & 100-150 ton segar & 9-13 ekor sapi (300kg) \\
\hline Euchlaena mexicana & $100-120$ ton segar & $9-11$ ekor sapi (300kg) \\
\hline
\end{tabular}

Sumber; Prawiradiputra. (2006), dalam Dwiyanto et al. (2010) 
S. Rusdiana, Cut R. Adawiyah : Analisis Ekonomi Dan Prospek Usaha Tanaman ...

Tabel. 9. Analisis Ekonomi Usaha Kelapa dan Sapi Potong, Sistem TBM, TM dan TTM/thn

\begin{tabular}{|c|c|}
\hline Usaha komoditas kelapa & Usaha Komoditas kelapa dan ternak \\
\hline \multicolumn{2}{|r|}{ TMB } \\
\hline Skala penanaman 120 pohon/ha & $\begin{array}{l}\text { Skala pemeliharaan } 3 \text { ekor ( } 2 \text { betina dewasa } 1 \\
\text { jantan dewasa) }\end{array}$ \\
\hline A. Biaya investasi & A. Biaya investasi \\
\hline \multirow[t]{3}{*}{ Bibit $=120$ pohon $=1.200 .000$} & bibit 2 ekor betina $=16.000 .000$ \\
\hline & 1 ekor jantan $=10.000 .000$ \\
\hline & Pembuatan kandang $=4.000 .000$ \\
\hline B. biaya operasional & B. Biaya operasional \\
\hline Penyulaman bibit 20 phon $=20.000$ & Penyusutan ternak betina $=857.000$ \\
\hline Pupuk urea $1 \mathrm{~kg} \times 1500 \times 120$ pohon $=180.000$ & Tenaga kerja keluarga $=1.200 .000$ \\
\hline Tenaga kerja $=2$ orang $=2.400 .000$ & Penyusutan kandang $=800.000$ \\
\hline Panenen & Jumlah biaya produksi $=2.857 .000$ \\
\hline C. Penerimaan & C. Penerimaan \\
\hline Pendapatan $=-3.780 .000$ & Penjualan anak 2 ekor $=8.000 .000$ \\
\hline Pendapatan $=-$ & Pendapatan $=5.143 .000 /$ thn \\
\hline Total pendapatan $=-$ & Total pendapatan $=5.143 .000$ \\
\hline
\end{tabular}

Keterangan= hijauan tidak beli mengandalkan di lahan kosong perkebunan kelapa

\begin{tabular}{|c|c|}
\hline \multicolumn{2}{|c|}{ TM } \\
\hline Skala penanaman 120.pohon/ha & $\begin{array}{l}\text { Skala pemeliharaan } 2 \text { ekor ( } 1 \text { betina dewasa } 1 \\
\text { jantan dewasa) }\end{array}$ \\
\hline A.Biaya investasi & A. Biaya investasi \\
\hline \multirow[t]{3}{*}{ Bibit $=120$ pohon $=1.200 .000$} & bibit 1 ekor betina $=8.000 .000$ \\
\hline & 1 ekor jantan $=10.000 .000$ \\
\hline & Pembuatan kandang $=2.000 .000$ \\
\hline B. biaya operasional & B. Biaya operasional \\
\hline Penyulaman bibit 20 phon $=200.000$ & Penyusutan ternak betina $=428.000$ \\
\hline Pupuk $=-$ & Tenaga kerja keluarga $=1.200 .000$ \\
\hline Tenaga kerja $=2$ orang $=2.400 .000$ & Penyusutan kandang $=400.000$ \\
\hline Panenen & Jumlah biaya produksi $=2.028 .000$ \\
\hline C. Penerimaan & C. Penerimaan \\
\hline $\begin{array}{l}\text { Penjualan kelapa } 4.500 \text { butir } \times \mathrm{Rp} 1.000= \\
6.750 .000\end{array}$ & Penjualan anak 1 ekor $=4.000 .000$ \\
\hline Pendapatan $=4.500 .000$ & Pendapatan $=1.972 .000$ \\
\hline Total pendapatan $=4.500 .000$ & Total pendapatan $=1.972 .000 /$ thn $/ \mathrm{ha}$ \\
\hline Keterangan $=$ hijauan tidak beli $m$ & han kosong perkebunan kelapa \\
\hline
\end{tabular}

\begin{tabular}{ll}
\hline & TTM \\
\hline Skala penanaman 120.pohon/ha & Skala pemeliharaan 2 ekor dewasa \\
A.Biaya investasi & A. Biaya investasi \\
Bibit $=120$ pohon $=120.000$ & bibit 2 ekor betina $=\mathrm{Rp} 10.000 .000$ \\
& Pembuatan kandang $=\mathrm{Rp} 2.000 .000$ \\
& Penyusutan kandnag $/ 5$ tahun $=\mathrm{Rp} 400.000$ \\
B. biaya operasional & B. Biaya operasional \\
Penyulaman bibit 20 phon $=20.000$ & Penyusutan ternak betina $=450.000$ \\
Pupuk $=-$ & Tenaga kerja keluarga $=1.200 .000$ \\
Tenaga kerja $=2$ orang $=2.400 .000$ & Jumlah biaya produksi $=\mathrm{Rp} 2.050 .000$ \\
Panenen & Jumlah biaya produksi $=$
\end{tabular}




\section{S. Rusdiana, Cut R. Adawiyah : Analisis Ekonomi Dan Prospek Usaha Tanaman ...}

C. Penerimaan

Penjualan kelapa 3.600 butir $\times$ Rp $1.000=$

3.600.000

Pendapatan $=1.200 .000$

Total pendapatan $=1.200 .000$
C. Penerimaan

Penjualan anak 2 ekor $=7.000 .000$

Pendapatan $=4.950 .000$

Total pendapatan $=4.950 .000$

Keterangan $=$ hijauan tidak beli mengandalkan di lahan kosong perkebunan kelapa

Tabel. 9 bahwa hasil analisis finansial secara ekonomi dari tanaman kelapa yang belum menghasilkan (TBM) mendapatkan keuntungan dari kelapa sekitar Rp3.780.000/ha karena belum menghasilkan buah kelapa yang artinya biaya masih dalam pemeliharaan tanaman kelapa sedangkan dari ternak sapi potong sekitar Rp5.143.000 tahun, sedangkan tanaman belum menghasilkan (TBM) mendapatkan keuntungan dari kelapa sekitar Rp6.750.000/tahun/ha dari ternak sapi potong sekitar Rp1.972.000/thn dan tanaman tidak menghasilkan atau tanaman rusak TTM/TR mendapatkan keuntungan dari kelapa sekitar Rp1.200.000/tahun sedangan dari ternak Rp4.950.000/tahun. Artinya pemanfaatan lahan kosong di perkebunan kelapa yang rusak dengan ternak sapi secara analisis finansial sangat menguntungkan, dan perlu di pertahankan keberadaan ternaknya. Perlu adanya peningkatan petani dalam usaha pemeliharaan ternak sapi potong dilhan lahan perkebunana kelapa yang tidak menghasilkan dapat dimanfaatkan hijauan pakan ternak yang tumbuh di lokasi lahan perkebunana kelapa petani.

\section{SIMPULAN}

Lahan kosong perkebunan kelapa dan tanaman kelapa dan ternak sapi dengan topografi yang bergelombang dapat dimanfaatkan secara maksimal melalui pendekatan ekosistem, baik melalui pola usaha tanaman ternak, rotasi tanaman ataupun usahatani campuran antara tanaman tahunan dan tanaman pangan yang berwawasan konservasi, ekonomi dan tanpa merusak lingkungan yang dapat bermanfaat dalam pemenuhan hijauan pakan ternak sapi sehingga mengurangi dalam pembiayaan usaha pemeliharaan ternak.

Analisis finansial secara ekonomi dari usaha tanaman kelapa yang belum menghasilkan (TBM) mendapatkan keuntungan dari kelapa sekitar Rp-3.780.000/ha karena belum menghasilkan buah kelapa yang artinya biaya masih dalam pemeliharaan tanaman kelapa sedangkan dari ternak sapi potong sekitar Rp5.143.000 tahun, sedangkan tanaman belum menghasilkan (TBM) mendapatkan keuntungan dari kelapa sekitar Rp6.750.000/ tahun/ha dari ternak sapi potong sekitar Rp1.972.000/thn dan tanaman tidak menghasilkan atau tanaman rusak TTM/TR mendapatkan keuntungan dari kelapa sekitar Rp1.200.000/tahun sedangan dari ternak Rp4.950.000/tahun. Artinya pemanfaatan lahan kosong di perkebunan kelapa yang rusak dengan ternak sapi secara analisis finansial sangat menguntungkan dan dapat di pertahankan keberadaan ternaknya. Perlu adanya peningkatan usaha pemeliharaan ternak sapi potong di lahan perkebunan kelapa yang tidak menghasilkan dengan memanfaatkan hijauan pakan yang tumbuh di lokasi tersebut.

\section{DAFTAR PUSTAKA}

Anwarhan.H. dan Sipriadi. 1997. Pengembangan teknologi sistem usahatani tanaman-ternak di lahan kering, Prosiding Simposium Penelitian Tanaman Pangan III. Puslitbang Tanaman Pangan. Balitbangtan Deptan, hal 1633-1645.

Arief dan Irman 1997.Ameliorasi lahan kering masam untuk tanaman pangan. Prosiding Simposium Penelitian Tanaman Pangan III Puslitbang Tanaman Pangan Balitbangtan Deptan, hal. 16651675

Arsyad.S.1989. Konservasi tanah dan air Penerbit IPB Cetakan I. Bogor, 290 hal.

Bamualim.A. 2010. Pengembangan teknologi pakan sapi potong di dearh semi arid Nusa Tenggara. Orasi Pengukuhan Profesor Riset Bidang Pemuliaan Ruminansia (Pakan dan Nutrisi Ternak). Badan Penelitian dan Pengembangan Pertanian Kemnetrian Pertanian Bogor, 29 Nopemebr hal. 1-59. 


\section{S. Rusdiana, Cut R. Adawiyah : Analisis Ekonomi Dan Prospek Usaha Tanaman ...}

Bamualim.A. Saleh. Afernadez.P.Th. dan C Liem. 1994. Komposisi jenis makanan yang diberikan petani pada ternak sapi yang dipelihara dengan sistem semiintensif di Nusa Tenggara. In Final Seminar of the Cattle Health and Productivity Survey (CHAPS) held at the Disease Investigation Centre, DenpasaBali, may 15-17-1994.CHAPS Book, hal 235-253.

Basri. I.H.1997.Budidaya Lorong di Lahan Kering Masam Prosiding Simposium Penelitian Tanaman Pangan III Puslitbangtan. Balitbangtan Deptan, hal 1687-1697.

Devendra 1993. Sustainable Animal Production from Small Farm Systems in South East Asia FAO Animal Production and Health Paper FAO Rome

Dwyanto.K. S.Rusdiana dan B.Wibowo. 2010. Pengembangan agribisnis sapi potong dalam suatu sistem usahatani kepala terpadu. Wartazoa Buletin Ilmu peternakan dan kesehatan Hewan Indonesia Pusat Penelitian dan Pengembangan Peternakan Vol.20 No.1 Maret 2010. Hal. 21-

Dwyanto.K. 2008. Pemanfaatan sumberdaya lokal dan inovasi teknologi dalam mendukung pengembangan sapi potong di Indonesia. Pengembangan Inovasi Pertanian, Vo. 1 No. 3, pp:173-188

Dwyanto. K. Sitompul. I, Manti., I., Mathius dan Soetoto. 2004. Pengkajian pengembangan usaha sistem integrasi kelapa sawit-sapi. Prosiding Lokakarya Nasional Sistem Integrasi Kelapa SawitSapi Bengkulu, 9-10 September 2003 Badan Penelitian dan Pengembangan Pertanian, Pemerintah Propinsi Bengkulu dan PT Agricinal. Bogor.

Direktirat Jenderal Perkebunan Jakarta. 2010. Statistik Perkebunan. Direktorat Jenderal Perkebunan, DEPTAN

Dinas Peternakan Kabupaten Bogor. 2012. Propinsi Jawa Barat. Data Statistik Peternakan
Gittinger.J.P. 1986. Analisis Ekonomi ProyekProyek Pertanian. Edisi Kedua. Universitas Indonesia. Jakarta.

Hakim, N, G. Ismail., Mardinus dan H. Muchtar. 1997. Perbaikan lahan kritis dengan rotasi tanaman dalam budidaya lorong Prosiding Simposium Penelitian Tanaman Pangan III Puslitbangtan, Deptan, hal 1656-1664

Kuswandi 2008. Kemungkinan Penggunaan lahan di antara tanaman kelapa untuk usaha ternak. Prosiding Simposium I Hasil Penelitian dan Pengembangan Tanaman Industri. Buku II.Badan Penelitian dan Pengembangan Pertanian. Pusat Penelitian dan Pengembangan Tanaman Industri.

Mubyarto.M 1980. Pengantar Ekonomi Pertanian. Penerbit LP3ES, Jakarta.

Noorginawati.,A. Jumberi dan Nur Tirtayanti. 1997. Perbaikan sistem usahatani di lahan kering beriklim basah di Kalimantan Selatan Prosiding Simposium Panelitian Tanaman Pangan III Puslitbangtan. Deptan, hal.1698-1706

Samingan.T.1998.Bahan Kuliah Mata Ajaran Ekologi Umum Program Studi Ilmu Pengelolaan Sumberdaya Alam dan Lingkungan. Program Pascasarjana IPB Bogor

Rahmawaty.S..2002. Rencana pemanfaatan lahan tidur berdasarkan pendekatan ekosistem.

repository.usu.ac.id/bitstream/12345620

02 digitized by USU digital library.http://repository. usu.ac.id/bitstream/123456789/936/1/ hutan-rahmawaty .pdf http:// www.g oogle.co.id/ search?hl=i d\&source= hp\&q= Rahmawaty \%, 27 Desember 2010 tanggal 5 Juni 2013.

Prawiradiputra.,R.B.Sajimin, Nurhayati,D. Dan Iwan,.H. 2006. Hijauan pakan ternak Indonesia. Badan Penelitian dan Pengembangan Pertanian. Depatemen Pertanian.

Haryanto.B.2009. Inovasi Teknologi Pakan Ternak dalam Sistem Integrasi Tanaman-Ternak Bebas Limbah 
S. Rusdiana, Cut R. Adawiyah : Analisis Ekonomi Dan Prospek Usaha Tanaman ...

Mendukung Upaya Peningkatan

Produksi Daging. Orasi Pengukuhan Prof, Riset Bidang Pakan Ternak Ruminansia. Badan Litbang Pertanian Deptan Bogor Maret 2009

Kusnadi. U. 2008.. Inovasi teknologi peternakan dalam system integrasi tanaman-ternak untuk menunjang swasembada daging sapi. Pengembangan Inovasi Pertanian, Vo. 1 No. 3, pp:189205

Luntungan.H.T.2008. Pelestarian sumber daya genetik kelapa sebagai komoditas unggulan dalam pengembangan lahan rawa pasang surut dan lebak. Pengembangan Inovasi Pertanian, Vo. 1 No. 4, pp:243-258

Mahmud.Z. 2008.. Modernisasi usahatani kelapa rakyat. Pengembangan Inovasi Pertanian, Vo. 1 No. 4, pp:274-287.

Mathius.I.2008 Pengembangan sapi potong berbasis industri kelapa sawit. Pengembangan Inovasi Pertanian, Vo. 1 No. 3, pp: 206-224.

Nittis.I.M.K.Lana dan A.W.Pugar. 2004. Pengalaman pengembangan tanamanternak berwawasan lingkungan di Bali. Prosiding Seminar Nasional Sistem
Integrasi Tanaman-Ternak. Denpasar 2022 Juli 2004. Pusat Penelitian dan Pengembangan Peternakan, Balai Pengkajian Teknologi Pertanian Provinsi Bali dan Crop-Animal System Research Network (CASREN). Bogor. pp: 44-52

Statistik Pekebunan dan Pertanian, 2009. Direktorat Jenderal Perkebunan, Deptan Jakarta

Subagyono. 2004. Prospek pengembangan ternak pola integrasi di kawasan perkebunan. Prosiding Seminar Nasional Sistem Integrasi Tanaman-Ternak. Denpasar 20-22 Juli 2004. Pusat Penelitian dan Pengembangan Peternakan, Balai Pengkajian Teknologi Pertanian Provinsi Bali dan Crop-Animal System Research Network (CASREN). Bogor. pp:13-17

Tikupandang.A., A. Prabowo dan D. Sugandi. 1995. Aspek tenaga kerja kelurga dalam sistem usahatani ternak terpadu di Daerah Transmigran Sulawesi Selatan. Prosiding Seminar Nasional Sains dan Teknologi Peternakan Pengelolaan dan Komunikasi Hasil-hasil Penelitian. Balai Penelitian Ternak Ciawi-Bogor, hal. 539545 